\title{
PEMIDANAAN KORPORASI
}

\author{
Rizal Arya Wibowo \\ Peneliti Profesional \\ Email: rizalaryawibowo@gmail.com
}

\begin{abstract}
The company is related to things that occur after the law that is related to corporate crime. The purpose of the discussion of this article is to find out about prison sentences imposed on corporations, detention and settlement of corporate criminal acts. The type of legal research conducted is a type of normative legal research that examines literature sources without conducting field research. The conclusion of this article is that it can be fined, approved and finalized.
\end{abstract}

Key word: Pemidanaan, Korporasi

\section{A. Pendahuluan}

Kejahatan yang dilakukan pada zaman ini berbeda dengan kejahatan yang dilakukan pada masa lampau. Setidaknya kejahatan yang dimaksud di sini adalah yang dianggap kejahatan oleh hukum atau kejahatan yang ditentukan bahwa suatu perbuatan tertentu merupakan kejahatan menurut hukum. Menurut hukum dalam hal ini adalah apa yang telah ditentukan sebagai delik kejahatan biasa atau delik aduan. Delik biasa adalah suatu kejahatan yang bisa diproses karena ada laporan atau tidak ada laporan. Sedangkan kalau delik aduan adalah faktor pelaporan merupakan hal yang mutlak ada terlebih dahulu sebelum kasus tersebut mulai dilakukan pemeriksaan atau penyelidikan serta penyidikan.

Kedua jenis delik tersebut di atas, dapat dilakukan oleh suatu korporasi. Korporasi yang dimaksud adalah yang sudah berbadan hukum. Berbadan hukum artinya telah didaftarkan atau telah memperoleh legalitas hukum dari negara mengenai kelayakan suatu usaha. Kejahatan yang dilakukan oleh korporasi memiliki kesulitan tersendiri dalam penanganannya. Kesulitan meminta pertanggungjawaban secara pidana kepada korporasi karena korporasi bukan personal. Karena korporasi bukan personal, maka itu artinya dapat melibatkan pihak lain sehingga agak kesulitan dalam melakukan penyelidikan atau penyidikan, terlebih lagi dalam hal pemidanaan. Dalinama Telaumbanua, 'Pertanggungjawaban Pidana Korporasi Lingkungan Hidup' (2015) 9 Jurnal Refleksi Hukum 106 mengatakan bahwa tindak pidana dapat diidentifikasikan dengan timbulnya kerugian, yang kemudian mengakibatkan lahirnya pertanggungjawaban pidana. Pertanggungjawaban 
pidana merupakan bentuk perlindungan hukum terhadap korban tindak pidana atas kerugian yang dideritanya. ${ }^{1}$

Oleh sebab itu, penulis tertarik menulis tentang pemidanaan korporasi dalam hal pemidanaan dalam bentuk pidana denda, penahanan, dan pengurangan pidana.

\section{B. Rumusan Masalah}

Rumusan masalah yang akan dibedah dalam tulisan ini yaitu:

1. Bagaimana jika korporasi melakukan tindak pidana hanya dijatuhkan pidana denda?

2. Apakah pada proses penyelidikan dapat dilakukan penahanan? Lalu bagaimana mekanisme pengurangan pidana?

\section{Pembahasan}

\section{Korporasi Dijatuhkan Pidana Denda}

Permasalahan pertanggungjawaban korporasi ini, penulis mengaitkan pertanggungjawaban pidana korporasi sebagai pelaku tindak pidana di bidang lingkungan hidup menurut UU Nomor 32 Tahun 2009 tentang Perlindungan dan Pengelolaan Lingkungan Hidup. Dimana dalam Pasal 116 ayat (1) dan (2) UU Nomor 32 Tahun 2009 menentukan bahwa:

(1) Apabila tindak pidana lingkungan hidup dilakukan oleh, untuk, atau atas nama badan usaha, tuntutan pidana dan sanksi pidana dijatuhkan kepada:

a. badan usaha; dan/atau

b. orang yang memberi perintah untuk melakukan tindak pidana tersebut atau orang yang bertindak sebagai pemimpin kegiatan dalam tindak pidana tersebut.

(2) Apabila tindak pidana lingkungan hidup sebagaimana dimaksud pada ayat (1) dilakukan oleh orang, yang berdasarkan hubungan kerja atau berdasarkan hubungan lain yang bertindak dalam lingkup kerja badan usaha, sanksi pidana dijatuhkan terhadap pemberi perintah atau pemimpin dalam tindak pidana tersebut tanpa memperhatikan tindak pidana tersebut dilakukan secara sendiri atau bersama-sama.

Selanjutnya ketentuan dalam Pasal 117 UU Nomor 32 Tahun 2009 menentukan bahwa jika tuntutan pidana diajukan kepada pemberi perintah atau pemimpin tindak pidana sebagaimana dimaksud dalam Pasal 116 ayat (1) huruf $b$, ancaman pidana yang dijatuhkan berupa pidana penjara dan denda diperberat dengan sepertiga.

1 Raganatha, B. S. (2017). Tinjauan Pertanggungjawaban Pidana Bagi Korporasi Yang Melakukan Insider Trading Dalam Pasar Modal. Refleksi Hukum: Jurnal Ilmu Hukum, 2(1), 17-32. 
Sistem pemberian pidana ini, dikaitkan dengan concursus realis2 dalam Pasal 66 KUHP yang mana Dalam hal perbarengan beberapa perbuatan yang masing-masing harus dipandang sebagai perbuatan yang berdiri sendiri sehingga merupakan beberapa kejahatan, yang diancam dengan pidana pokok yang tidak sejenis, maka dijatuhkan pidana atas tiap-tiap kejahatan, tetapi jumlahnya tidak boleh melebihi maksimum pidana yang terberat ditambah sepertiga. sementara pidana denda adalah hal itu dihitung menurut lamanya maksimum pidana kurungan pengganti yang ditentukan untuk perbuatan itu.

Contohnya: Jika A melakukan 2 jenis Kejahatan yang masing-masing dipidana penjara paling lama 1 (satu) tahun dan denda paling banyak Rp.3.000.000.000,00 (tiga miliar rupiah). Dalam hal ini semua jenis pidana (penjara dan Denda) harus dijatuhkan. jadi Rp.3.000.000.000,00 + (1/3 X Rp.3.000.000.000,00)= Rp. 4.000.000.000,00. (Sistem ini disebut sistem Kumulasi yang diperlunak).

Selain pidana sebagaimana dimaksud dalam undang-undang ini, terhadap badan usaha dapat dikenakan pidana tambahan atau tindakan tata tertib berupa3:

a. perampasan keuntungan yang diperoleh dari tindak pidana;

b. penutupan seluruh atau sebagian tempat usaha dan/atau kegiatan;

c. perbaikan akibat tindak pidana;

d. kewajiban mengerjakan apa yang dilalaikan tanpa hak; dan/atau

e. penempatan perusahaan di bawah pengampuan paling lama 3 (tiga) tahun.

Dalam melaksanakan ketentuan ini, jaksa berkoordinasi dengan instansi yang bertanggung jawab di bidang perlindungan dan pengelolaan lingkungan hidup untuk melaksanakan eksekusi.

Sehingga tindak pidana yang dijatuhkan pada korporasi tidak hanya pidana denda, akan tetapi juga mencakup pidana penjara jika tindak pidana lingkungan hidup dilakukan oleh orang, yang berdasarkan hubungan kerja atau berdasarkan hubungan lain yang bertindak dalam lingkup kerja badan usaha, sanksi pidana dijatuhkan terhadap pemberi perintah atau pemimpin dalam tindak pidana tersebut tanpa memperhatikan tindak pidana tersebut dilakukan secara sendiri atau bersama-sama.

\section{Penahanan Pada Proses Penyelidikan serta Mekanisme Pengurangan Pidana}

2 Arief, Barda Nawawi, Sari Kuliah Hukum Pidana II, Badan Penyediaan Bahan Kuliah Fakultas Hukum Universitas Diponegoro, Semarang, 1984.

3 Pasal 119 UU No.32 tahun 2009 tentang Perlindungan dan Pengolahan Lingkungan Hidup 
Berdasarkan ketentuan dalam Pasal 20 KUHAP, untuk kepentingan penyidikan, penyidik atau penyidik pembantu atas perintah penyidik, berwenang melakukan penahanan. Perintah penahanan atau penahanan lanjutan dilakukan terhadap seorang tersangka atau terdakwa yang diduga keras melakukan tindak pidana berdasarkan bukti yang cukup, dalam hal adanya keadaan yang menimbulkan kekhawatiran bahwa tersangka atau terdakwa akan melarikan diri, merusak atau menghilangkan barang bukti dan atau mengulangi tindak pidana.

Penahanan atau penahanan lanjutan dilakukan oleh penyidik atau penuntut umum terhadap tersangka atau terdakwa dengan memberikan surat perintah penahanan atau penetapan hakim yang mencantumkan identitas tersangka atau terdakwa dan menyebutkan alasan penahanan serta uraian singkat perkara kejahatan yang disangkakan atau didakwakan serta tempat yang bersangkutan ditahan. Tembusan surat perintah penahanan atau penahanan lanjutan atau penetapan hakim sebagaimana dimaksud pada ayat (2) harus diberikan kepada keluarganya4. Jenis penahanan tersebut dapat berupa:

a. penahanan rumah tahanan negara;

b. penahanan rumah;

Penahanan rumah dilaksanakan di rumah tempat tinggal atau rumah kediaman tersangka atau terdakwa dengan mengadakan pengawasan terhadapnya untuk menghindarkan segala sesuatu yang dapat menimbulkan kesulitan dalam penyidikan, penuntutan atau pemeriksaan di sidang pengadilan.

c. penahanan kota.

Penahanan kota dilaksanakan di kota tempat tinggal atau tempat kediamati tersangka atau terdakwa, dengan kewajiban bagi tersangka atau terdakwa melapor din pada waktu yang ditentukan.

Jika mengacu pada Pasal 24 KUHAP, maka perintah penahanan yang diberikan oleh penyidik hanya berlaku paling lama dua puluh hari. Jangka waktu tersebut apabila diperlukan guna kepentingan pemeriksaan yang belum selesai, dapat diperpanjang oleh penuntut umum yang berwenang untuk paling lama empat puluh hari. Hal ini tidak menutup kemungkinan dikeluarkannya tersangka dan tahanan sebelum berakhir waktu penahanan tersebut, jika kepentingan pemeriksaan sudah terpenuhi. sehingga setelah waktu enam puluh hari tersebut, penyidik harus sudah mengeluarkan tersangka dan tahanan demi hukum. 
Oleh karena itu masa penangkapan dan atau penahanan dikurangkan seluruhnya dan pidana yang dijatuhkan. untuk penahanan rumah sepertiga dari jumlah lamanya waktu penahanan. sementara untuk penahanan kota pengurangan tersebut seperlima dari jumlah lamanya waktu penahanan. Jika masa tahanannya 60 hari dari pidana penjara 1 tahun (365 hari) maka cara pengurangan dari ketiga jenis penahannya yaitu:

a. Rutan: 1 (seluruhnya)

$1 \times 60$ hari $=60$ hari

Jadi masa hukuman dikurangi masa tahanan $(365-60)=305$ hari

b. Rumah: $1 / 3$

$1 / 3 \times 60$ hari $=20$ hari

Jadi masa hukuman dikurangi masa tahanan $(365-20)=345$ hari

c. Kota: $1 / 5$

$1 / 5 \times 60$ hari $=12$ hari

Jadi masa hukuman dikurangi masa tahanan $(365-12)=353$ hari

\section{Kesimpulan}

Berdasarkan pembahasan tersebut, maka dapat disimpulkan bahwa korporasi ketika melakukan tindak pidana, bisa hanya dengan pidana denda yang dapat dijatuhkan terhadap pemberi perintah atau pemimpin dalam tindak pidana tersebut tanpa memperhatikan tindak pidana tersebut dilakukan secara sendiri atau bersama-sama. Penahanan dapat dilakukan kepada tersangka tindak pidana korporasi pada proses penyelidikan ketika unsur objektif dan/atau unsur subjektif penahanan terpenuhi. Ketika pelaku tindak pidana korporasi telah selesai diperiksa dan dinyatakan terbukti melakukan tindak pidana, maka pengurangan pidana atau hukuman dapat dilakukan ketika sebelumnya pelaku telah menjalani masa penahanan.

\section{E. Referensi}

Arief, Barda Nawawi. "Sari Kuliah Hukum Pidana II." Semarang: Universitas Diponegoro (1984).

Telaumbanua, Dalinama. 2019. Hukum Ketenagakerjaan. Deepublish.

Telaumbanua, Dalinama. 2018. "Pembentukan Peraturan Daerah Kabupaten/Kota.” Jurnal Education and Development. vol. 4, no. 1

Kitab Undang-Undang Hukum Pidana. 
Kitab Undang-Undang Hukum Acara Pidana.

Undang-Undang Republik Indonesia Nomor 32 Tahun 2009 tentang Perlindungan dan Pengelolaan Lingkungan Hidup. 